\title{
Assessing the challenges and initiatives to increase women's integration into science in Madagascar
}

\author{
Voahangy Tinah Martin', Hanitra Rakotonirina", \\ Veronarindra Ramananjatoll, IV, Lalao A. \\ Ravaoarinorotsihoaranav, Onja H. Razafindratsimalv, \\ Mialy Razanajatovo VI, VII, Ny Riavo G. VoarintsoaVIII
}

\author{
Correspondence: \\ Voahangy Tinah Martin \\ Columbia Climate School Lamont-Doherty Earth Observatory \\ P.O. Box 1000 \\ 61 Route 9W, Palisades, NY, USA \\ Email: vtm2109@columbia.edu
}

\begin{abstract}
We present here a commentary essay on the challenges and perspectives on the recruitment and retention of Malagasy women in STEM (Science, Technology, Engineering, and Mathematics). We base the essay on our personal experience as Malagasy women scientists and support the arguments with the responses of 60 Malagasy women scientists to an online survey that was shared among Malagasy scientists. We identified that the main causes for a limited number of Malagasy women in STEM relied upon traditional expectations and heavily ingrained cultural values. The situation becomes more complicated when accounting for familial constraints, financial constraints, and communication gaps between students and professors. This is obviously an unfortunate situation; however, there have been bridging-gap initiativesfinancial, awareness to family pressure, and knowledge difference between senior and junior scientists-that should be continued to provide support to promising students and enhance STEM education as a tool for development in Madagascar.
\end{abstract}

\section{RÉSUMÉ}

Cet essai discute les défis et les perspectives dans le recrutement et le maintien des femmes citoyennes de Madagascar dans les sciences, la technologie, l'ingénierie et les mathématiques (STIM). Les arguments présentés sont basés sur nos expériences personnelles en tant que femmes scientifiques nées et ayant grandies à Madagascar. Ces arguments sont soutenus par des informations issues d'un sondage effectué en ligne auprès de 60 femmes scientifiques, s'identifiant elles-mêmes originaires de Madagascar. Les raisons pour lesquelles ces femmes sont peu nombreuses à participer activement dans les domaines des STIM à Madagascar sont liées à des contraintes traditionnelles et à des valeurs culturelles fortement ancrées depuis leur enfance. La situation se complique Iorsqu'on tient compte des contraintes financières et des écarts de communication entre étudiants et professeurs. Si cette situation est évidemment regrettable, il existe cependant des initiatives visant à combler le fossé qui sont financières, ou qui s'inscrivent dans la sensibilisation à la pression familiale et à la différence de connaissances entre les scientifiques seniors et juniors. Ces encouragements devraient être poursuivis afin d'apporter un soutien aux étudiantes prometteuses et d'améliorer l'enseignement des femmes en STIM qui sont importantes pour le développement de Madagascar.

\section{INTRODUCTION}

The role of women in science (a relative term that we use here to collectively refer to Science, Technology, Engineering, and Mathematics-STEM) is as important and crucial as their role in society (Harding 1998, Fox 2001). The involvement of women in the scientific workforce has, for instance, provided opportunities toward increasing social justice, gender equity, and reduction in poverty (Harding 1998). However, the worldwide percentage of women versus men in the scientific workforce is still relatively low with a global average of 29.3\% (UNESCO 2019), leaving a significant gap in gender-equal contributions towards science and the society (Blickenstaff 2005, Larivière et al. 2013, Clark et al. 2017). This gap could worsen if one considers the level of education, race, ethnicity, or other society-driven factors. Recent studies have additionally highlighted that, globally, women tend to publish less peerreviewed scientific articles and lead fewer scientific disciplines than men (Larivière et al. 2013, West et al. 2013). Such bias has become more pronounced since the COVID-19 pandemic (UN Women 2020, Viglione 2020, Vincent-Lamare et al. 2020)

In Madagascar, gender bias is still heavily felt at various scales (Rabenoro 2012). Despite the high level of girls' enrollment in schooling at an early stage (Gastineau and Ravaozanany 2011, Rabenoro 2012), the percentage of women's enrollment in the 


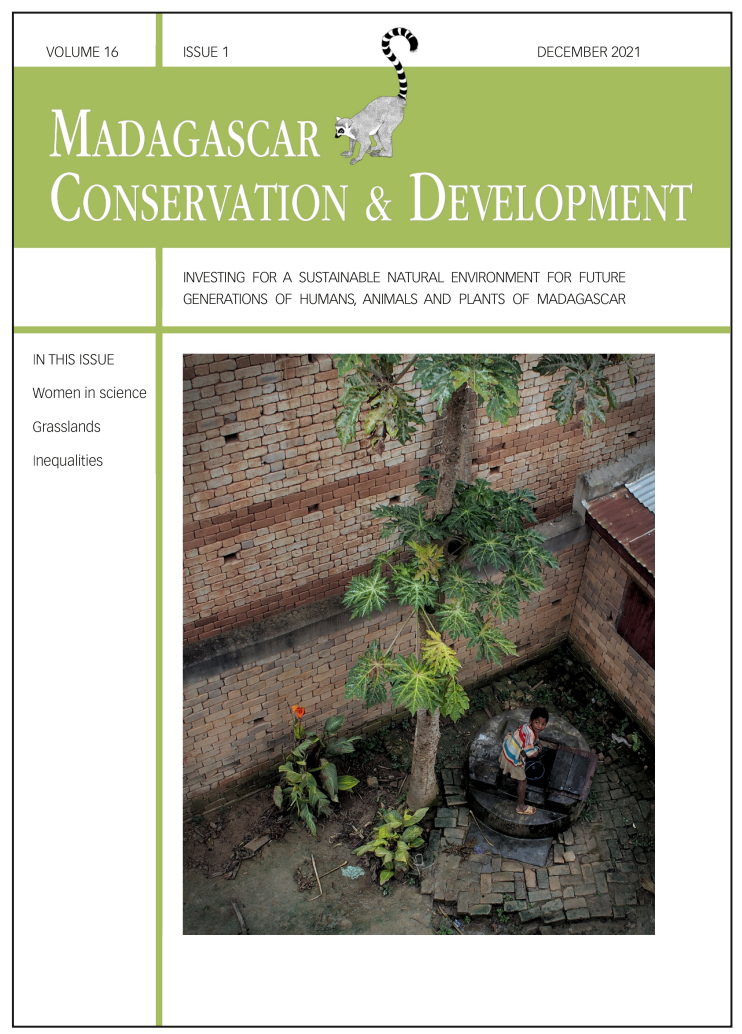

Madagascar Conservation \& Development is the journal of Indian Ocean e-Ink. It is produced under the responsibility of this institution. The views expressed in contributions to MCD are solely those of the authors and not those of the journal editors or the publisher.

All the Issues and articles are freely available at https://www.journalmcd.com

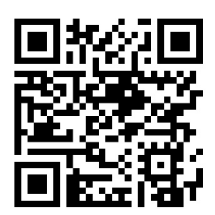

Contact Journal MCD

info@journalmcd.net for general inquiries regarding MCD funding@journalmcd.net to support the journal

Madagascar Conservation \& Development Institute and Museum of Anthropology

University of Zurich

Winterthurerstrasse 190

CH-8057 Zurich

Switzerland

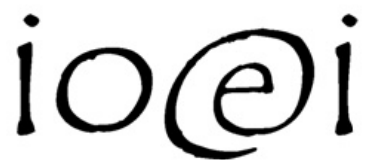

Indian Ocean e-Ink

Promoting African Publishing and Education

www.ioeink.com

Missouri Botanical Garden (MBG)

Madagascar Research and Conservation Program

敨 Missouri Botanical Garden BP3391

Antananarivo, 101, Madagascar 
STEM-fields decreases with the level of education. Only $35 \%$ of Malagasy scientists are women, and the number of women enrolled in universities beyond B.Sc. and M.Sc. degrees dramatically decreases (UNESCO 2016). Although it decreased to $32.9 \%$ in 2018, this number is slightly higher than that of Sub-Saharan Africa (UNESCO 2019). If we look closer at student enrollment at the University of Antananarivo, which represents about $44 \%$ of enrolled students in all six provinces of Madagascar (MESUPRES 2014a), there is substantially lower integration of women in Ph.D. programs in some scientific fields (Figure 1). This reduction in higher-level enrollment is associated with a combination of factors, similar to what has been observed globally. These usually include local history, early age stereotyping, cultural background, religious belief, family pressures, lack of senior female role models, lack of governmental funding, and the existence of an unwelcoming environment for women in science classes and other academic settings - an environment considered a "chilly climate" (Duteil 2009, Gastineau and Ravaozanany 2011, Sugimoto 2013, UNESCO 2016, Clark et al. 2017).

In this essay, we aim to highlight some major challenges faced by Malagasy women in STEM and discuss the variety of initiatives that have been implemented with success to leverage gender diversity in STEM in Madagascar. We also seek to provide insights and perspectives on how to improve these initiatives to reach a sustainable development goal, aiming at minimizing gender bias towards equality and empowering all women, not only those at higher levels (university) but also those at lower-level education who aspire to pursue a career in STEM.

While some of the aspects discussed in this essay are based on our personal knowledge and experience as being Malagasy women scientists, i.e., born and raised in Madagascar, we support our viewpoints with published information from peer-reviewed journal articles and from public domains. To back up the accountability of our own experience, we conducted a structured online survey using Google Forms (see questionnaires in Supplementary Material), disseminated on Facebook between February and March 2018. This survey was accessible to everyone. Facebook was chosen as the main platform for disseminating the survey because it is the most used and the most easily accessible means of social media in Madagascar. We received 80 responses, $75 \%$ of which were from women in STEM (60 individuals, $78 \%$ of which were in Sciences, $2 \%$ in Technology, $11 \%$ in Engineering, and the rest classified as 'Others'). These participants owned at least a B.Sc. degree, started university studies between 1980 and 2014 and finished their highest degree between 1991 and 2018. Among the remaining $25 \%$ respondents, 11 (14\%) were not affiliated with any STEM field and therefore did not continue with the rest of the survey; nine (11\%) were men. The analyses presented here were from these 60

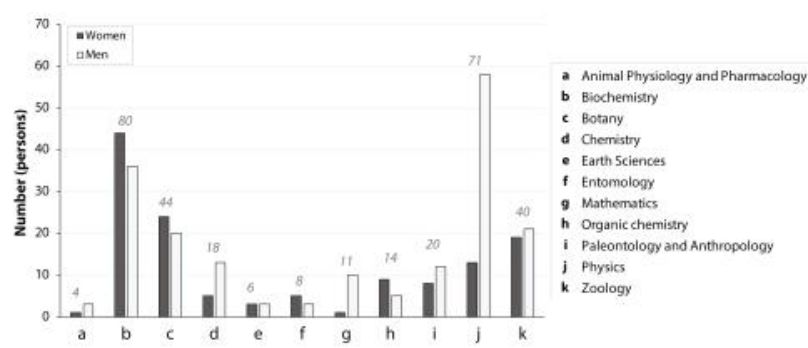

Figure 1. Number of doctorates and higher level-degree recipients at the Faculty of Sciences of the University of Antananarivo, grouped by gender, from 2000 to 2013 (V. Jeannoda, unpublished data). The italic numbers above the bars represent the total of male (black bars) and female (grey bars) degree recipients. women in STEM and our personal experience. We understand that our survey data is not comprehensive and may be biased, especially given that the respondents are female scientists that overcame the challenges. However, we believe that they are invaluable to help us understand better the challenges and opportunities for the recruitment and retention of Malagasy women in STEM.

\section{CHALLENGES FACED BY MALAGASY WOMEN IN STEM} challenges experienced by Malagasy women enrolled in STEM studies include financial constraints (68.3\%), communication gaps between professors and students (35\%), family pressure (28.3\%), political instability $(26.7 \%)$, lack of female role model $(21.7 \%)$, and other minor but influencing factors such as the lack of education among parents (5\%), peer-pressure (8.33\%), and culture (8.33\%) (Figure 2). The remaining $10 \%$ of these challenges were not specified in the survey results. Many of these factors appear to be exacerbated by Malagasy colonial history and conservative culture, like what was highlighted by observations of Malagasy women pursuing higher education in another study in the region of Toliara (Skjortnes and Zachariassen 2010).

FINANCIAL CONSTRAINTS AND POLITICAL INSTABILITY. Many families in Madagascar are poor (with at least 75\% of the population living under $\$ 1.90$ a day, World Bank 2019); most parents cannot afford to support their children to continue education beyond elementary or high school (Moreira et al. 2017). This financial constraint is often aggravated by the prevalent political instability. For instance, we have experienced negative impacts from the 2002 and 2009 political crises, through a delayed starting date of the academic year and change in the schedule of national exams, both at the university and at lower-level education. These situations extended the duration of the academic year, forcing many students in need of more funds than expected to support their education. Besides, scientific research requires adequate funding to be successful, but Madagascar does not have its own national funding agency to support its researchers; only a handful of funding opportunities targeted to support young Malagasy scientists are available in Madagascar (Randriamahenintsoa 2013). For example, national public spending on education was below $4 \%$ despite the GDP increase in 2003-2007 and only 13-18\% of the national budget was allocated to education (Randiamahenintsoa 2013). In the national budget for 2021 , only $0.01 \%$ of the total proposed budget is allo-

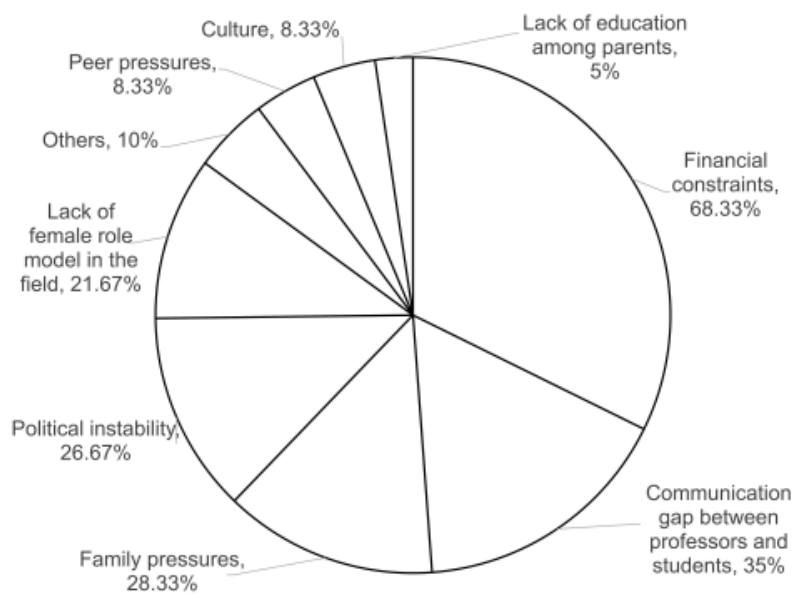

Figure 2. The different challenges faced by Malagasy women in STEM that may hinder their ability to pursue a career in those fields (data collated from an online survey conducted in February 2018; $\mathrm{N}=60$ women in STEM). 
cated to higher education and scientific research, and only $4 \%$ of this is for actual scientific research (MEFB 2021). Most of the financial support comes from foreign collaboration (Waeber et al. 2016), and even in such circumstances, the number and the amount are unequal among different disciplines. One obvious example is the distribution and allocation of funds during COVID-19 times. Even though such situations affect both genders, women tend to be more vulnerable to the burden they may represent in their families (Skjortnes and Zachariassen 2010, Gastineau and Ravaozanany 2011). Additionally, women at a very young age often bear the costs of education dropout during economic shocks in middle-class Malagasy families (Gubert and Robilliard 2008). Thus, choosing a less expensive and less time-consuming major seems to be an adequate and wise decision to promote others' success, here, represented by the men of the family.

COMMUNICATION GAP BETWEEN PROFESSORS AND STUDENTS. Malagasy university students often have a passive attitude when interacting with some educators, especially if the latter have stronger opinions, an attitude that makes them unapproachable. This, of course, is not always the case in Madagascar as a few professors are more approachable and more encouraging, supporting the success and professional development of their female students. The problematic communication type is exacerbated by the fact that most professors in Madagascar are men (Hayward and Rasoanampoizina 2015), and strongly rooted cultural attitudes venerating older men and reluctance to speak in mixedgender settings often prevent female students from communicating freely with professors. Interactions with students are limited to monologues of professors lecturing during classes, as has been common in colonial period (Duteil 2009), rather than helping and preparing the students to become future educators or leaders. In this scenario, it has often been considered disrespectful if students boldly criticize seniors and express their opinions, even with valid arguments (Rakotonanahary 2019), hence leaving a cold and unwelcoming learning environment. This student-professor interaction is additionally compromised because of the traditional stereotyping of women in the society and their fear of appearing stupid. The lack of warm communication between professors and students can hinder the latter's personal development and their acquisition of scientific knowledge and skills, as they may feel insecure and lack self-esteem to undertake a career in science, which is qualified as a tough field in Madagascar. This communication gap could affect not only women but also men; it represents one third of each gender in our survey. As recorded from the survey respondents' answers, among the nine male participants, three of them identified this gap as a challenge, and among the 60 women participants, 21 identified this gap.

This gap is not only felt at the intellectual level but also at the age level. Following a hiring freeze in the civil service in the 1980s and 1990s (IMF 1997), there was no recruitment and/or promotion of university professors from 1986 to 2006 at most of the universities in Madagascar (Gerety 2017), leading to a decrease in the number of new university professors between 2006 and 2014 (MESUPRES 2014b). This has resulted in an increasing age gap between students and professors over the years, and potentially could have enhanced gender discrimination and eventually the colonial behavior of the 'old' professors towards their potential 'successors'.
FAMILY PRESSURES. alagasy societies hold very strong and highly conservative views in all aspects, including the role attributed to and expected from women, generally a housewife or the doer of soft jobs, which often conflicts with the women's career path in science (Skjortnes and Zachariassen 2010, AEFE 2012). Even if Madagascar has advanced on gender justice by reducing gender inequity while supporting schooling young girls up into higher education (Gubert and Robilliard 2008, Gastineau and Ravaozanany 2011) - with almost half of university students being women (Mama 2003), the culture belittled the strength of women. There is a tacit expectation that women-even if well educated-are the caregivers for the immediate and extended family (Gubert and Robilliard 2008, Gastineau and Ravaozanany 2011, AEFE 2012). Despite a saying in Madagascar "Education is the best legacy" ("Ny fianarana no lova tsara indrindra"), obtaining a degree and pursuing a successful career path in a STEM field, unfortunately, remains a synonym of sacrifice. Furthermore, while Malagasy women are expected to have children at an age deemed optimal by the family and the society, usually in their 20s, the lack of an adequate societal system in morally and financially supporting families with young children represents a barrier. Furthermore, having many children is still perceived as a blessing in Madagascar. With such an engraved mindset, junior female scientists are afraid to compromise their family life. Young Malagasy women are often not attracted to a scientific career, often viewed as a highly demanding position. In fact, most women are often told that the time involved and the responsibilities taken towards work as a scientist (supplementary hours, repetitive fieldwork and travel abroad) may drive negligence in their children's education and emotions (Sonnert and Holton 1995, Skjortnes and Zachariassen 2010). Consequently, the chances for Malagasy women scientists to achieve their scientific career goals are likely to decrease under these circumstances.

LACK OF FEMALE ROLE MODELS IN THE FIELD. Young Malagasy women lack senior female role models in STEM. Although they exist, illustrating the possibility of overcoming gender barriers to achieve success in these fields is daunting. Students and junior women scientists often do not have good perspectives on the scientific activities that potential role models could show them, such as producing new articles, getting grants, and obtaining leadership positions. Because very few Malagasy women appear to have a successful career in STEM (UNESCO 2016), many young women tend to think that such fields are not for them (Blickenstaff 2005). Moreover, the fear of not having a good work-life balance is often discouraging to young women.

LACK OF EDUCATION AMONG PARENTS. The lack of parental education sometimes represents a critical challenge for many Malagasy, irrespective of gender, to choose a scientific career path. While the overall literacy rate is relatively high in Madagascar $(\sim 71 \%)$, the older generations are more likely to be illiterate than younger ones (UNESCO 2018), and more than $50 \%$ of the workforce in Madagascar has no formal education (Stifel et al. 2007). The low level of parental education has been associated with limited financial resources, limited access to health care, and poor quality of education of children, which is observed in many societies worldwide (Flores et al. 1999). While this lack of parental education can affect the opportunities and achievements for both genders, its impact can be stronger on women when it is combined with the tradition- 
ally male-centric societal values and some anti-feminist attitude in Madagascar (Rabenoro 2012).

Parents with minimal education levels are more likely to underestimate the value of science as a tool for their children's development, which is in fact the foundation of several countries' success and development (van Driel et al. 2001, Bernardes and Albuquerque 2003). These parents do not understand the benefits of having well-educated children in promoting scientific and societal values. Indeed, parents' low education-level might be more likely to advise their children to pursue a non-scientific/academic career in which the returns are directly visible in a timely manner (Nguyen 2008). In contrast, investment in education and academic career means putting money upfront for years, with no insurance of increased return. In fact, potential returns are only felt within many years after the investments, something that people living in low-income countries cannot afford. This may be felt more in girls and young women because of a stronger fear of taking risks. From this standpoint, STEM may not be an attractive discipline for Malagasy women when enrolling at the university level. The financial benefits of scientific research may, depending on the field, only be applicable, felt, and visible after quite a long time, as explained earlier. For these reasons, young Malagasy women are missing the necessary guidance and support to become a confident STEM-researcher and scientific leader.

OTHER CHALLENGES FACED BY MALAGASY WOMEN IN STEM.

Other challenges include the lack of inclusive opportunities, the lack of perspectives, the lack of resources and the lack of connection with foreign institutions. Even though each of these listed factors is important, it is quite difficult to assess which ones weigh more than the others in influencing Malagasy women's successful scientific career. In our view, these factors can be grouped into two categories: internal (i.e., more personal) vs. external categories (i.e., with more external influence). Internal categories group both the lack of ambition and the evidence of peer pressure. They seem to be complementary factors halting the ambitious goal of pursuing a career in STEM. External categories combine the absence of inclusive opportunities and international connections, which could enhance women's scientific and academic growth. Both internal and external factors, however, are like 'chicken-and-eggs', in a way that more opportunities could increase the motivation and the ambition of women to pursue a STEM-oriented career. On the other hand, external funders should support more scientific activities with an inclusive approach to attract more women to a STEM career.

\section{INITIATIVES IMPLEMENTED TO LEVERAGE GENDER DIVERSITY IN STEM IN MADAGASCAR}

Governments and non-governmental organizations (NGOS), private sectors, universities, and individuals have implemented several initiatives, as detailed below, to increase and retain the enrollment of women in STEM fields in Madagascar. In addition, many groups of Malagasy women have advanced into making changes either individually or by forming networks. For example, the Association Ikala STEM (https://www.ikalastem.org/), founded in 2016 and run by Malagasy women has a mission to "empower the next generation of women in STEM in Madagascar" and acts upon reaching that objective. With such initiatives, Ikala STEM has been shortlisted among the top five global initiatives for the Nature Research Awards for inspiring women in STEM. We further discuss the interventions, programs, and other incentives that have encouraged
Malagasy female scientists to overcome these above-mentioned challenges. In the discussion, we provide arguments based on our own experience and our personal involvement in these initiatives. We additionally include the supporting responses from the 60 surveyed women in STEM, as presented in Figure 3.

NETWORKING. Collaboration with peers and sharing of know-

ledge constitute important pillars for advancing science. Evidence-based methods are used worldwide to promote ethics and learning in science, as well as to involve future scientists in it. Networking can also expand one's access to the crucial role models that are lacking in their own community. Increasing the numbers of female models known in different areas of research is favorable to inspire and raise the participation of young female scientists (Ibarra 1993, Breda et al. 2020). Among the benefits from belonging to a network is the confidence to share knowledge and the sense of STEM identity, both can affect achievements and increase interests (Wiest 2014, Seyranian et al. 2018). Malagasy women are keen to step forward with the raising of a new generation of scientists that are ready to improve the participation of women in science.

INTERVENTIONS OF NGOS AND PRIVATE ORGANIZATIONS.

Several NGOS and different associations (all termed 'organization' in this paper), either at national or international levels, have been contributing to empowering Malagasy women in science, by enhancing their ability to develop themselves in the field of science and offering them the possibility to get assistance from other scientists to improve on their scientific skills. At the national levels, these come in the form of funding Malagasy female student researchers to address the challenge of financial constraints (e.g., Small Grants provided by Malagasy women-run Ikala STEM: https:// www.ikalastem.org/news-room/categories/small-grants), providing professional development and capacity building opportunities (e.g., Django Girls' coding initiative: https://djangogirls.org/antananarivo/) and offering mentorship to female students (e.g. Ikala STEM's mentoring program: https://www.ikalastem.org/news-room/categories/ mentoring). Several organizations have implemented different scientific projects involving Malagasy women (e.g., Association vahatra, Madagasikara Voakajy, and GERP), in which Malagasy female scientists are not only involved in research but also supervise and guide other young women in their scientific studies. At the international level, several organizations have taken initiatives to support female scientists from developing countries to pursue academic

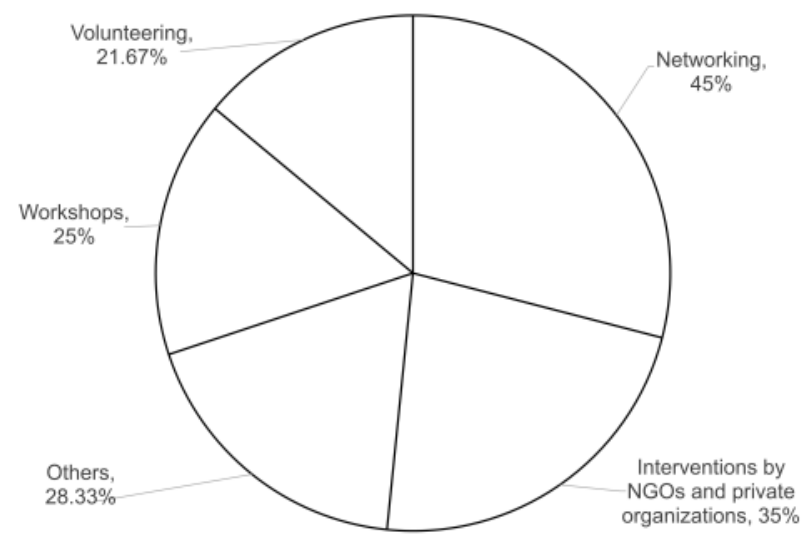

Figure 3. The different initiatives undertaken by Malagasy women in STEM during their STEM-academic milestones (data collated from an online survey conducted in February 2018; $\mathrm{N}=60$ women in STEM). 
studies at reputed host institutions, e.g., the Schlumberger Foundation Faculty for the Future has supported at least five Malagasy women so far in their academic field of studies, many of whom are leaders in their field. Other institutions are specialized in solely supporting young scientists from the developing world, such as The World Academy of Sciences (TWAS; twas.org) and the AuthorAid program, which offers several training curricula to enhance the academic capabilities of young scientists from developing countries.

Besides these, what is more attractive and inspiring is when Malagasy women are actively participating in any relevant scientific organization. They become role models for young girls, thus reducing the 'lack of Malagasy role models' that we have identified as a challenge. From such active participation, young female scientists can gain experiences, enhance their learning skills, and expand their knowledge. The exchange of practical advice among members of the scientific committees within the organization as well is also beneficial. With all these positive benefits from being active in STEM-related activities, encouraging and motivating Malagasy women to get themselves active in different science-oriented organizations can also be relevant to improve their scientific skills. Promoting the success of these role models can also inspire young women to pursue a career in STEM.

More inclusive opportunities should also be put forward. Specific opportunities for women to help them build a career and limit their excellence in their careers. Such opportunities are perceived among Malagasy society as a 'personal kick-off', without which women cannot succeed (Astuti and Bloch 2015), especially when they are given a quota. Even the granted women would feel troubled when confronted with such a situation, belittle themselves as incompetent, and become unconfident, which would discourage them to excel and step up their careers. Organizations should thus offer an equal number and consideration to men and women instead of just placing women in a position over a demanded quota. For example, applying for a position or funding open to both genders could increase women's competitiveness, and add to their acquired competencies to overcome other general issues and challenges on top of gender inequality.

PARTICIPATION IN TRAINING OPPORTUNITIES. Intellectual ex-

change platforms such as workshops, conferences, and seminars provide many opportunities for learning, gaining new experiences, and growing a professional network. For women in science, participating in such platforms is a great opportunity to learn to communicate their own work to other participants, and share their interests. More importantly, since workshops are considered as educational opportunities, participating in them increases levels of networking. Meeting people with the same field of interest may provide different advice to improve their own skills. For Malagasy women, scientific workshops are relevant to improve their communication skills (especially oral communication) not only via networking but also via the presentation of their own work in an open and comfortable environment. In this way, they learn to raise their voice and share their own work with other experts with confidence. Due to cultural norms, Malagasy women are often expected to refrain from being vocal (Ramamonjisoa 1993, Razafindratsima and Dunham 2015). Thus, having a platform where they are encouraged to speak up is particularly important. Attending workshops allows them to strengthen their scientific skills but also gives them inten- sive knowledge on a specific theme via presentations and discussions.

Apart from these above-mentioned benefits, being the organizer of scientific workshops is also important for Malagasy women in science. They learn not only to plan different scientific programs but, most importantly, they can professionally develop and confidently shape their scientific expertise. Attending or organizing educational platforms, therefore, plays an important role for Malagasy women in the field of science as they have a lot to offer but also learn many new things.

VOLUNTEERING. Based on the survey data and our own experience, volunteering is an important tool for Malagasy scientists' personal growth. The existence of movements promoting young women such as supporting their integration in Information Technology (Women in Tech Madagascar: http://pointgg.com/ women-in-tech-madagascar/), providing mentoring (Ikala STEM mentoring program) and bringing them to participate in activities that allow them to interact and learn about STEM is a promising start. This early education awareness brings about change in the perception of science.

\section{LOOKING FORWARD}

One cannot deny the many challenges that prevent women in Madagascar from pursuing a career in STEM, but there is also room for opportunities to improve the recruitment and retention of women in the STEM workforce. Even though Malagasy girls dream of becoming 'a scientist' at a young age, that dream vanishes when life becomes difficult and requires more responsibilities, hence the 'leaky pipeline' that needs to be fixed. Initiatives have been taken and have been successful to encourage Malagasy women participation in science, but given that the current percentage of female scientists is still lower than the percentage of male scientists, we need to (1) enhance the initiatives that are already successful to keep them in the STEM workforce, (2) develop some initiatives that can help break gaps between students and professors (e.g., via mentoring and training dedicated to addressing specific issues) for mutual benefit, (3) establish some funding bodies/agencies to provide partial or full support to promising students in need, and (4) enhance science education as a tool for development in Madagascar. Additionally, there is a need to better inform parents and the community about the benefits of involving girls in STEM. More importantly, we need to promote the success of Malagasy women scientists to inspire girls because science is not only the art of conveying what is important in gathering data and defining a new trend of evolution but also it is the art of conveying oneself to be a role model and a leader in one's field so a change can be initiated.

\section{ACKNOWLEDGEMENTS}

We are grateful to Dr. Victor Jeannoda and the Life Sciences graduate school of the University of Antananarivo for sharing the data presented in Figure 1. We thank all the survey participants for giving us permission to analyze, investigate, and share the data here. We also thank Drs. Zara Randriamanakoto and Nirilanto Ramamonjisoa for useful feedback. 


\section{REFERENCES}

AEFE, Agence pour l'Enseignement Français à l'Étranger. 2012. L'égalité filles/ garçons, hommes/femmes à Madagascar. Dossier documentaire. Available online

<http://aefe-madagascar.histegeo.org/IMG/pdf/

dossier_FG_HF_Madagascar_AeH.pdf >

Astuti, R. and Bloch, M. 2015. The causal cognition of wrong doing: incest, intentionality, and morality. Frontiers in Psychology 6: 136. $<$ https://doi.org/10.3389/fpsyg.2015.00136>

Bernardes, A. T. and Albuquerque, E. M. 2003. Cross-over, thresholds, and interactions between science and technology: lessons for less-developed countries. Research Policy 32, 5: 865-885. <https://doi.org/10.1016/S0048-7333(02)00089-6>

Blickenstaff, J. C. 2005. Women and science careers: leaky pipeline or gender filter? Gender and Education 17, 4: 369-386. <https://doi.org/10.1080/09540250500145072>

Breda, T., Grenet, J., Monnet, M. and Van Effenterre, C. 2020. Do female role models reduce the gender gap in science? Evidence from French high schools (No. 13163). Institute of Labor Economics (IZA). Accessed 24 November 2021 $<$ https://halshs.archives-ouvertes.fr/halshs-01713068/>

Clark, J., Zuccala, E. and Horton, R. 2017. Women in science, medicine, and global health: call for papers. The Lancet 390, 10111: 2423-2424. <https://doi.org/10.1016/S0140-6736(17)32903-3>

Duteil, S. 2009. Enseignants coloniaux. Madagascar, 1896-1960. Ph.D thesis, Université Le Havre, Havre. Available online $<$ https://doi.org/10.4000/dhfles.2131>

Flores, G., Bauchner, H., Feinstein, A. R. and Nguyen, U. S. 1999. The impact of ethnicity, family income, and parental education on children's health and use of health services. American Journal of Public Health 89:1066-1071. $<$ https://doi.org/10.2105\%2Fajph.89.7.1066>

Fox, M. F. 2001. Women, science, and academia: Graduate education and careers. Gender \& Society 15, 5: 654-666. <https://doi.org/10.1177/089124301015005002>

Gastineau, B. \& Ravaozanany, N. 2011. Genre et scolarisation à Madagascar. Questions Vives. Recherches en Éducation 8, 15. <https://doi.org/10.4000/questionsvives.710>

Gerety, R. M. 2017. Building conservation's brain trust in Madagascar. Mongabay series: Conservation in Madagascar. Available online <https://news.mongabay.com/2017/10/building-conservations-brain-trust-inmadagascar/>

Gubert, F. and Robilliard, A.-S. 2008. Risk and schooling decisions in rural Madagascar: A panel data-analysis. Journal of African Economies 17, 2: 207238. <https://doi.org/10.1093/jae/ejm010>

Harding, S. 1998. Women, science, and society. Science 281, 5383: 1599-1600. <https://doi.org/10.1126/SCIENCE.281.5383.1599>

Hayward, F. and Rasoanampoizina, H. 2015. Planning for higher education change in Madagascar. International Higher Education 46:18-20. <https://doi.org/10.6017/ihe.2007.46.7934>

Ibarra, H. 1993. Personal networks of women and minorities in management: A conceptual framework. The Academy of Management Review 18, 1: 56-87. <https://doi.org/10.2307/258823>

IMF, International Monetary Fund. 1997. A decade of civil service reform in SubSaharan Africa. Working Paper of the International Monetary Fund. Available online <https://www.imf.org/external/pubs/ft/wp/wp97179.pdf>

Larivière, V., Ni, C., Gingras, Y., Cronin, B. and Sugimoto, C. 2013. Bibliometrics: Global gender disparities in science. Nature 504: 211-213. $<$ https://doi.org/10.1038/504211a>

Mama, A. 2003. Restore, reform but do not transform: The gender politics of higher education in Africa. Journal of Higher Education in Africa / Revue de l'Enseignement Supérieur en Afrique 1, 1: 101-125. <http://www.jstor.org/stable/24486116>

MEFB, Ministère de l'Économie, des Finances et du Budget. 2021. Loi n 2021-017 du 04 août 2021 portant sur la Loi de Finances Rectificatives 2021. Ministère de l'Économie et des Finances à Madagascar, Antananarivo. Accessed 24 November 2021 <http://www.mef.gov.mg/dgcf/info\%20utiles/5113.pdf>
MESUPRES, Ministère de I'Enseignement Supérieur et de la Recherche Scientifique) 2014a. Effectifs des étudiants par université public, année universitaire 20132014.

MESUPRES. 2014b. Évolution du personnel enseignant 2005-2014.

Moreira, C. N., Rabenevanana, M. W. and Picard, D. 2017. Boys go fishing, girls work at home: gender roles, poverty and unequal school access among seminomadic fishing communities in South Western Madagascar. Compare: A Journal of Comparative and International Education 47, 4: 499-511. <https://doi.org/10.1080/03057925.2016.1253456>

Nguyen, T. 2008. Information, role models and perceived returns to education: Experimental evidence from Madagascar. MIT Working Paper. Available online $<$ https://www.povertyactionlab.org/sites/default/files/documents/ Nguyen\%202008.pdf>

Rabenoro, M. 2012. Le mythe des femmes au pouvoir, arme de l'antiféminisme à Madagascar. Cahiers du Genre 1: 75-95. <https://doi.org/10.7202/1011116ar>

Rakotonanahary, M. L. 2019. Collège de Madagascar: le curriculum formel, appui ou obstacle à l'apprentissage des sciences physiques? Revue Didaktika 3: 2442. Available online <http://madarevues.recherches.gov.mg/IMG/pdf/art2.pdf>

Ramamonjisoa, S. 1993. Empowerment of women and democracy in Madagascar. Review of African Political Economy 20, 58: 118-123. <https://doi.org/10.1080/03056249308704028>

Randriamahenintsoa, E. 2013. Challenges and opportunities of higher education funding policies and programs in Madagascar. In: Funding Higher education in Sub-Saharan Africa. D. Teferra (eds.), pp 147-183. Palgrave Macmillan UK, London. <https://doi.org/10.1057/9781137345783_7>

Razafindratsima, O. H. and Dunham, A. E. 2015. Increasing women's participation in community based conservation: Key to success? Madagascar Conservation \& Development 10, 2: 45-47. <https://doi.org/10.4314/mcd.v10i2.1>

Seyranian, V., Madva, A., Duong, N., Abramzon, N., Tibbetts, Y. and Harackiewicz, J. M. 2018. The longitudinal effects of STEM identity and gender on flourishing and achievement in college physics. International Journal of STEM Education 5 : 40. <https://doi.org/10.1186/s40594-018-0137-0>

Skjortnes, M. and Holt Zachariassen, H. 2010. 'Even with higher education you remain a woman': a gender perspective on higher education and social change in the Toliara region of Madagascar. Gender and Education 22, 2: 193207. <https://doi.org/10.1080/09540250902749075>

Sonnert, G. and Holton, G. J. 1995. Who Succeeds in Science? The Gender Dimension. Rutgers University Press, New Brunswick.

Stifel, D., Rakotomanana, F. H. and Celada, E. 2007. Assessing labor market conditions in Madagascar, 2001-2005. World Bank, Washington, DC, USA. Available online <https://documents1.worldbank.org/curated/en/207511468270305133/pdf/ 418910MGOLaborOmarkets0wp10501PUBLIC1.pdf>

UN Women, United Nations Women, International Development Law Organization, United Nations Development Programme, United Nations Office on Drugs and Crime, World Bank and The Pathfinders. 2020. Justice for women amidst COVID-19. UN Women, IDLO, UNDP, UNDOC, World Bank and The Pathfinders, New York. Available online

$<$ https://www.unwomen.org/en/digital-library/publications/2020/05/justicefor-women-amidst-covid-19>

UNESCO, United Nations Education, Scientific and Cultural Organization). 2016 Rapport de I'UNESCO sur la Science, vers 2030. UNESCO, Paris. Available online

$<$ https://fr.unesco.org/sites/default/files/usr15_focus_subsaharan_africa_fr.pdf>

UNESCO. 2018. Madagascar. Éducation et Alphabétisme. Available online <http://uis.unesco.org/fr/country/mg>

UNESCO. 2019. Women in Science. Fact Sheet No. 565. Available online <http://uis.unesco.org/sites/default/files/documents/fs55-women-inscience-2019-en.pdf>

van Driel, J. H., Beijaard, D. and Verloop, N. 2001. Professional development and reform in science education: The role of teachers' practical knowledge. Journal of Research in Science Teaching: The Official Journal of the National Association for Research in Science Teaching 38, 2: 137-158. <https://doi.org/10.1002/1098-2736(200102)38:2<137::AIDTEA1001>3.0.CO;2-U> 
Viglione, G. 2020. Are women publishing less during the pandemic? Here's what the data say. Nature 581: 365-366

$<$ https://doi.org/10.1038/d41586-020-01294-9>

Vincent-Lamare, P., Sugimoto, C. R. and Larivière, V. 2020. Monitoring women's scholarly production during the COVID-19 pandemic. Accessed 24 November $2021<$ http://shiny.initiativesnumeriques.org/monitoring-scholarly-covid/>

Waeber, P. O., Wilmé, L., Mercier, J.-R., Camara, C. and Lowry II, P. P. 2016. How effective have thirty years of internationally driven conservation and development efforts been in Madagascar? PLoS ONE 11: e0161115. $<$ https://doi.org/10.1371/journal.pone.0161115>

West, J. D., Jacquet, J., King, M. M., Correll, S. J. and Bergstrom, C. T. 2013. The role of gender in scholarly authorship. PLOS ONE 8: e66212. <https://doi.org/10.1371/journal.pone.0066212>

Wiest, L. R. 2014. Strategies for Educators to support Females in STEM. University of Nevada, Reno. Accessed 24 November 2021

$<$ https://www.unr.edu/education/centers-and-student-resources/initiatives/ northern-nevada-math-technology-program/math-tips/educator-support-ofstem>

World Bank. 2019. The World Bank in Madagascar. Accessed 24 November 2021 <https://www.worldbank.org/en/country/madagascar/overview\#1> 